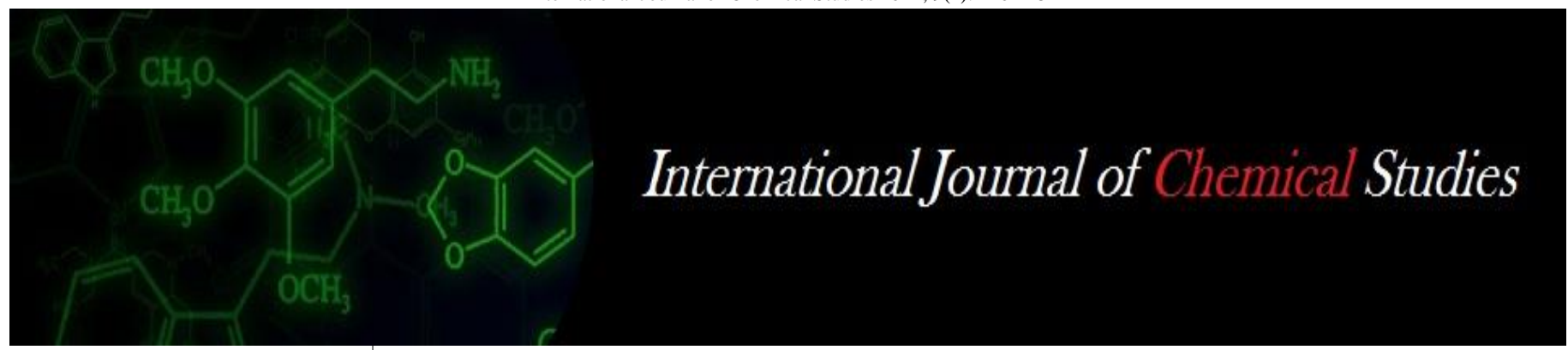

P-ISSN: 2349-8528

E-ISSN: 2321-4902

www.chemijournal.com

IJCS 2021; 9(1): 410-415

(C) 2021 IJCS

Received: 13-10-2020

Accepted: 28-11-2020

\section{Bharati Killadi}

Division of Post Harvest

Management, ICAR-CISH,

Rehmankhera, Lucknow, Uttar

Pradesh, India

PS Gurjar

Division of Post Harvest

Management, ICAR-CISH

Rehmankhera, Lucknow, Uttar

Pradesh, India

Jotirmayee Lenka

Division of Post Harvest

Management, ICAR-CISH,

Rehmankhera, Lucknow, Uttar

Pradesh, India

Rekha Chaurasia

Division of Post Harvest

Management, ICAR-CISH,

Rehmankhera, Lucknow, Uttar

Pradesh, India

\section{DK Shukla}

Division of Post Harvest

Management, ICAR-CISH,

Rehmankhera, Lucknow, Uttar

Pradesh, India
Corresponding Author:

Bharati Killadi

Division of Post Harvest

Management, ICAR-CISH,

Rehmankhera, Lucknow, Uttar

Pradesh, India

\section{Optimization of hot water treatment of guava fruits cv. 'Shweta' to prolong cold storage}

\author{
Bharati Killadi, PS Gurjar, Jotirmayee Lenka, Rekha Chaurasia and DK \\ Shukla
}

DOI: https://doi.org/10.22271/chemi.2021.v9.i1f.11262

\begin{abstract}
In north India, winter guava crop is harvested in the coldest month of the year, yet it poses a challenge in post-harvest life due to its perishable nature. There is also concern about the use of any pesticide/chemicals for extension of shelf life in guava as fruits are consumed with peel and fresh. To prolong the shelf life of guava fruits use of cold storage is alternative but being a subtropical fruit, it is sensitive to low temperature. Therefore, an alternative mode to enhance the self-life of fruits by optimising hot water treatment and storage at low temperature was worked out. Mature fruits of guava were treated at $45{ }^{\circ} \mathrm{C}, 50{ }^{\circ} \mathrm{C}, 55{ }^{\circ} \mathrm{C}$ with check (normal tap water) for 3 minutes and stored at low temperature of $5 \pm 2{ }^{\circ} \mathrm{C}$ and 85 to 90 per cent R.H. Fruits were withdrawn at weekly interval and assessed for physico-chemical parameters. The cumulative physiological loss in weight (CPLW) per cent was maximum in control fruits ( 10.88 per cent), while it was minimum ( 8.66 per cent) in fruits treated with hot water at $45^{\circ} \mathrm{C}$. The total soluble solid (TSS) was $12.2^{\circ} \mathrm{Brix}$ in fruits treated with hot water at $45^{\circ} \mathrm{C}$. The acidity of the fruits decreased with increase in storage. In fruits treated with hot water at $50{ }^{\circ} \mathrm{C}$, the ascorbic acid content of the fruits was maximum $274.16 \mathrm{mg} / 100 \mathrm{~g}$ after 21 days of storage and minimum $114.05 \mathrm{mg} / 100 \mathrm{~g}$ after 28 days of storage. The total polyphenols content of the fruits decreased with increase in storage life. Conclusively fruits treated with hot water at $45^{\circ} \mathrm{C}$ could be stored up to 28 days + 3 days under room temperature.
\end{abstract}

Keywords: Shelf-life, physico-chemical parameters, ascorbic acid, total polyphenols, antioxidants

\section{Introduction}

Guava is consumed fresh and also processed for its palatable flavour and taste. It is a rich source of dietary fibre, polyphenols and minerals. Guava fruits are highly nutritious in nature because it contains high levels of ascorbic acid (50 to $300 \mathrm{mg} / 100 \mathrm{~g}$ fresh weight), which is three to six times higher than oranges. Guava is a climacteric fruits with a limited shelf life. The quality decreases rapidly once harvested at colour breaking stage. To extend the shelf life of the fresh fruits many technologies are being used, such as reduced storage temperature, dip treatments with ethylene suppressors, external coatings, modified and controlled atmospheric storage, etc. Post harvest thermotherapy or heat treatments are being used for a long time for disease control, to modify the responses of fruits to stresses and maintain fruit quality during storage in many fruits. (Armstrong et al., 1989; Couey, 1989; Klein and Lurie, 1990; Paull, 1994; Paull and McDonald, 1994; Lurie, 1998; McDonald et al., 1999) ${ }^{[2,8,23,21,15,19]}$. It is advocated that heat treatment exposure to the fruits to temperatures $40-42^{\circ} \mathrm{C}$ increases the storage life and flavour of fruits (Barber and Sharpe, 1971 and Lurie, 1998) ${ }^{[4,15]}$. Higher temperature $>45^{\circ} \mathrm{C}$ are associated with skin scald and heat injury (Paull and Chen; 2000) ${ }^{[22]}$. Symptom development of fruits when subjected to hot water treatment and exposure time is well documented in banana (Armstrong, 1982) ${ }^{[1]}$ and oranges (Williams et al., 1994) ${ }^{[35]}$. Fruit maturation stage is an important factor influencing its susceptibility to chilling injury. Guava fruits harvested at colour turning stage could be stored for 3 weeks at $7^{\circ} \mathrm{C}$ with good appearance quality and less decay then those harvested at mature green stage (Vazquez-Ochoa and Colina-Leon, 1990) ${ }^{[31]}$. Guava is reportedly sensitive to heat treatments as it affects the fruit quality varying from slightly to adversely (Gould and Sharp, 1992; Yusof and Hashim, 1992 and Monzon et al., 2004) ${ }^{[11,37]}$ therefore it is imperative to maintain guava fruit at 
optimum temperature to avoid chilling injury during the supply chain. Different temperatures treatments are recommended for guava fruits depending on the cultivars, growing environment and cultural practices. In north Indian conditions winter crop is quality crop but despite quality fruits it has very short shelf life of 4-6 days only under ambient conditions. Shelf life of guava fruits needs to be increased by some safe method. Hot water treatments of guava for prolonging the shelf life are not well studied. Hot water treatments (at different temperatures) in combination with cold storage were tried for desired result and to establish the relationship between thermotherapy and cold treatment on the antioxidants, phytochemical concentration and quality of fruits.

\section{Materials and Methods}

Fruits of guava cv. Shweta used for this study were harvested from the orchards of ICAR-Central Institute for Subtropical Horticulture were brought to Post Harvest Management Lab for further treatments. The fruits were divided into four lots, weighed and subjected separately to hot water treatment at $45^{\circ} \mathrm{C}, 50^{\circ} \mathrm{C}, 55^{\circ} \mathrm{C}$ and control (normal water) for 3 minutes and stored under cold temperature $\left(5 \pm 2{ }^{\circ} \mathrm{C}\right.$ and $85-90 \%$ R.H $)$. The fruits were periodically sampled at 7 days intervals and following physico-chemical quality parameters were analysed as mentioned below.

Physical attributes: Fruits were weighed at different sampling intervals. Then the weight lost was calculated as the difference between initial fruit weight and the fruit weight at the time of measurement and expressed as cumulative physiological weight loss (CPLW percentage). Firmness of the fruit was measured with the help of penetrometre $(8 \mathrm{~mm}$ probe, USA) and expressed as $\mathrm{kg} / \mathrm{cm}^{2}$.

\section{Biochemical attributes}

Electrolyte leakage (per cent): The method described by McCollum and McDonald (1991) ${ }^{[18]}$ was used to determine the rate of electrolyte leakage. For each fruit, six discs of peel tissue (10 $\mathrm{mm}$ in diameter) were cut at random using a cork borer. The electrical conductivity (EC1) was measured using a conductivity meter after $3 \mathrm{~h}$ incubation in $25 \mathrm{ml}$ of $0.4 \mathrm{M}$ mannitol at $25{ }^{\circ} \mathrm{C}$ with constant shaking. After recording EC1, each sample was boiled for $20 \mathrm{~min}$, cooled to room temperature, and the electrical conductivity was measured again (EC2) as an indicator of the total electrolytes released. The level of electrolyte leakage was then expressed as a percentage of the total electrolyte reading.

Electrolyte leakage $(\mathrm{EL})=\frac{\mathrm{EC} 1}{\mathrm{EC} 2} \mathrm{X} \frac{100}{1}$

Fruits were finely cut and approximately $200 \mathrm{~g}$ were ground to pulp using a blender and samples were weighed and analysed for biochemical parameters as follows: Total soluble solid or soluble solid content (SSC) with help of refractometer model PAL-1 (Atago, Tokyo, Japan) and tritatable acidity (TA) ascorbic acid in fruit pulp was estimated by method as outlined by Ranganna (2000) ${ }^{[26]}$.

Total phenols (TP): The total phenolics was estimated according to the methodology of (Singleton et al., 1999) [29] by use of Folin-Ciocalteu reagents and gallic acid as standard for reference. Sample of $0.2 \mathrm{ml}$ of each were taken in a test tube and $0.5 \mathrm{ml}$ of Folin-Ciacalteu phenol reagent was added. The tubes were maintained at room temperature for $5 \mathrm{~min}$. afterward, $0.4 \mathrm{ml}$ of $7.5 \%$ sodium carbonate was added and shaken well the samples were incubated at $25^{\circ} \mathrm{C}$ for $60 \mathrm{~min}$. The absorbance was measured at $750 \mathrm{~nm}$ with a UV/visible spectrophotometer. The standard curve was prepared with gallic acid. The results were expressed as milligram gallic acid equivalents (GAE/100g).

Total flavonoid: Flavonoid content was determined as described by (Zhishen et al. 1999) ${ }^{[38]}$. The sample methanol extract $(1 \mathrm{ml})$ was mixed with $4 \mathrm{ml}$ of water and $300 \mu \mathrm{L}$ of $5 \%$ $\mathrm{NaNO}_{2}$. The mixture was agitated and incubated for 5 minutes, followed by the addition of $300 \mu \mathrm{L}$ of $\mathrm{AlCl}_{3}(10 \%)$ and incubated for 1 minute. Two $\mathrm{ml}$ of $1 \mathrm{M} \mathrm{NaOH}$ and $\mathrm{H}_{2} \mathrm{O}$ were added, the volume was made $10 \mathrm{ml}$ and absorbance was measured at $415 \mathrm{~nm}$. Results were expressed as milligram quercetin equivalent per gram fresh weight $(\mathrm{QE} / \mathrm{g} \mathrm{FW})$.

Antioxidants (FRAP and DPPH): FRAP assay was done as per the methodology of Benzie and Strain (1996) ${ }^{[5]}$ in ethanol and methanol extract of sample. The reduction of a ferrictripyridyltriazine complex to its ferrous, coloured form in the presence of antioxidants is the principle of the assay. The FRAP agent contained $2.5 \mathrm{ml}$ of a $10 \mathrm{mmol}^{-1} \mathrm{TPTZ}(2,4,6-$ tripyridy-s-triazine, Sigma) solution in $40 \mathrm{mmol}^{-1} \mathrm{HCL}$ plus $2.5 \mathrm{ml}$ of $20 \mathrm{mmol}^{-1} \mathrm{FeCl}_{3}$ and $25 \mathrm{ml}$ of $0.3 \mathrm{~mol}^{-1}$ acetate buffer, $\mathrm{pH} 3.6$ and was prepared freshly and warmed at $37^{\circ} \mathrm{C}$. Aliquots of $40 \mu \mathrm{l}$ sample supernatant were mixed with $0.2 \mathrm{ml}$ distilled water and $1.8 \mathrm{ml}$ FRAP reagent and the reaction mixture was incubated at $37^{\circ} \mathrm{C}$ for $10 \mathrm{~min}$. and absorbance measured by spectrophotometer at $593 \mathrm{~nm}$. The standard solution used was $1 \mathrm{mmol}^{-1}$ Trolox and the final result was expressed as the concentration of antioxidants as micromoles trolox equivalent/g FW (mmoles TE/g FW). The 2, 2diphenyl-1-picrylhydrazyl (DPPH) estimation was done according to the method of Brand-Williams et al., (1995). DPPH was weighed $(24 \mathrm{mg}$ ) and dissolved in $100 \mathrm{ml}$ methanol which served as stock solution and stored at $-20^{\circ} \mathrm{C}$ until needed. The working solution was obtained by mixing $10 \mathrm{ml}$ of stock solution with $45 \mathrm{ml}$ methanol to get an absorbance of $1.1 \pm 0.02$ units at $515 \mathrm{~nm}$ using the spectrophotometer. Fruit extracts of $150 \mu \mathrm{L}$ were allowed to react with $2850 \mathrm{ml}$ of DPPH solution for 24 hours in the dark. Then the absorbance was read at $515 \mathrm{~nm}$. The results were expressed as per cent inhibition.

\section{Results and Discussion}

The CPLW per cent of guava fruits was significantly affected $(p \leq 0.05)$ by hot water treatments during the period of 28 days of storage (Table1). Control fruits of guava showed significantly higher CPLW during the early days of storage, which gradually increased during the later period of storage. Desiccation became noticeable on fruit surface which accounts for $>10 \%$ of their FW. Among the treatments, hot water $45{ }^{\circ} \mathrm{C}$ for $3 \mathrm{~min}$ was effective in reducing CPLW. At the end of storage (28 days), the highest percentage of CPLW $(10.88 \%)$ was recorded in control fruits, while it was lowest $(8.66 \%)$ in hot water $45^{\circ} \mathrm{C}$ for 3 min treated guava fruits.

Evaporation from fruit surface during storage becomes apparent as desiccation. The lower CPLW in fruits treated with hot water $45{ }^{\circ} \mathrm{C}$ for 3 min during cold storage could be related to the lower severity of chilling injury (Gould and Sharp, 1992; Yusuf and Hashim, 1992 and Monzon et al., 2004) ${ }^{[11,37]}$. Hot water temperature significantly affected the percentage of weight loss of dragon fruit (Lum and Norazira, 2011) ${ }^{[16]}$. 
The firmness of the fruits data revealed that, irrespective of treatment, there was a gradual decline in fruit firmness in storage though it was comparatively less in hot water treated fruits (Table 1). Hot water treatments were effective in maintaining reasonably higher value of fruit firmness up to 14 days of storage in cold storage which remained reasonably well up to 21 days. On $28^{\text {th }}$ day highest firmness (8.33 $\mathrm{kg} / \mathrm{cm}^{2}$ ) was retained in fruits treated with hot water treatment with $45^{\circ} \mathrm{C}$, while it was lowest $\left(5.47 \mathrm{~kg} / \mathrm{cm}^{2}\right)$ in control guava fruits. Among quality attributes, firmness of fruits is important and determines the consumer's acceptability. In this study, the softening of guava fruit was delayed significantly by hot water treatment prior to cold storage (Table 1). Ethylene is responsible for post-harvest softening/ripening in climacteric fruits. After heat treatments or thermotherapy, cell wall degrading enzymes and ethylene production is disrupted and sometimes not produced (Paull and Chen 2000) ${ }^{[22]}$. (Yu et al.; 1980, Atta Aly, 1992) ${ }^{[36,3]}$ advocated that first type of heat response is normal cellular response $\left(<42^{\circ} \mathrm{C}\right)$ that can lead to reduced chilling sensitivity, delayed or slowed ripening and a modification of quality. The second is threshold for damage $>45{ }^{\circ} \mathrm{C}$ that modifies the cellular response to stress and its recovery. Temperatures $>35^{\circ} \mathrm{C}$ can cause an accumulation in endogenous ACC (1aminocyclopropane-1-carboxylic acid) content in apple and tomato. (Briggs et al., 1988; Klein 1989) ${ }^{[6,12]}$ found reduced ethylene production in fruits. (Lum and Norazira, 2011) ${ }^{[16]}$. Also found that hot water temperature significantly affected the percentage of firmness of dragon fruit. Our findings are also in agreement with the above findings.

Electrolytic leakage (EL) gradually increased in all treatments (Table 1.) and varied significantly $(p \pm 0.05)$ throughout the storage period of 28 days. In early days of storage, control fruits exhibited higher per cent of EL, which later increased with a faster rate than in fruits treated with hot water. At $45^{\circ} \mathrm{C}$ increase in per cent of EL was at lowest rate up to 28 days of storage (53.85).

The physical state of membrane lipids changes from liquidcrystalline to a solid-gel under low temperature conditions, which leads to an increase in membrane permeability and ion leakage as reported by (Gomez-Galindo et al., 2004) ${ }^{[10]}$. Total soluble solid (TSS) degree brix and titratable acidity per cent data revealed that TSS increased while the TA decreased gradually during the entire storage period of 28 days (Table 1.). Among the treatments, maximum TSS $\left(12.17^{\circ} \mathrm{B}\right)$ was noted in control and fruits treated at $50^{\circ} \mathrm{C}$ on the $14^{\text {th }}$ day of storage. The TA was maximum $(0.48 \%)$ in fruits treated with hot water $45^{\circ} \mathrm{C}$ on $14^{\text {th }}$ day, while it was minimum $(0.27 \%)$ in fruits on the $21^{\text {st }}$ day of storage. (Lum and Norazira, 2011) ${ }^{[16]}$ also advocated that hot water temperature significantly affected the percentage of TA of dragon fruit.

The ascorbic acid content in guava fruits varied significantly $(p \leq 0.05)$ during storage period of 28 days (Fig.1.A). Ascorbic acid content was maximum $(274.17 \mathrm{mg} / 100 \mathrm{~g})$ in fruits treated with hot water at $50^{\circ} \mathrm{C}$ on the 21 day of storage, while it was minimum $(110.76 \mathrm{mg} / 100 \mathrm{~g})$ in fruits treated with hot water at $55^{\circ} \mathrm{C}$ on the $28^{\text {th }}$ day. The ascorbic acid content declined gradually from 21 day to 28 day of storage period. In untreated control fruits it reached the highest on the $14^{\text {th }}$ day of storage and decreased thereafter. Loss of vitamin C during post harvest is unclear due to temperature and water loss during storage (Paull, 1999) ${ }^{[22]}$. Hot water treatment at $50^{\circ} \mathrm{C}$ did not affect the ascorbic acid content of Satsuma mandarin (Shen Yu et al., 2013) ${ }^{[27]}$.

Total polyphenols content among the treatments varied significantly $(p \leq 0.05)$ during the entire period of storage (28 d) of the fruits at temperature $5 \pm 2{ }^{\circ} \mathrm{C}$ and relative humidity of 85-90 per cent (Fig.1.B.). On the day of harvest guava fruits had total phenol content of $2.16 \mathrm{mg}$ GAE/ $100 \mathrm{~g}$, which in general decreased in all treatments during the storage period. Fruits treated with hot water at $45^{\circ} \mathrm{C}$ had highest polyphenols (2.53 $\mathrm{mg} \mathrm{GAE} / 100 \mathrm{~g})$ on the 21 day of storage and it was least $(1.29 \mathrm{mg} \mathrm{GAE} / 100 \mathrm{~g})$ in fruits treated at $50{ }^{\circ} \mathrm{C}$ on the 28 day. During the entire period of storage ( 28 days), guava fruits exhibited significant $(p \leq 0.05)$ changes in the total flavonoid content (Fig.1C.). Among the hot water treatments highest (6.26 mg QE/g FW) flavonoid content in fruits with hot water at $55^{\circ} \mathrm{C}$ on the 7 day, while it was least $(0.59 \mathrm{mg} \mathrm{QE} / \mathrm{g} \mathrm{FW})$ in control fruits on the $28^{\text {th }}$ day.

The protective effect of a short heat stress could be through interruption of normal metabolic process or inhibiting the synthesis of enzymes. Browning is prevented by the heat stress response only in the tissues with initially low level of phenolic compounds and low level of phenylpropanoid enzyme activity. The slight heat stress that prevents browning is due to rise in PAL (phenylalanine ammonia-lyase) activity Loaiza-Velarde et al., (1997). Significant increases of flavonoids were found in hot water treated fruits of Satsuma mandarin till 15 days of storage (Shen Yu et al., 2013) ${ }^{[27]}$.

Antioxidants estimated by FRAP and DPPH method varied significantly $(p \leq 0.05)$ in hot water treated fruits of guava throughout the period of 28 days (Fig.1D\&1E.). In the estimation of antioxidants by FRAP method there was decrease in antioxidant on the $14^{\text {th }}$ day of storage and thereafter increased on the $28^{\text {th }}$ day in all the treatment of ethanol extract. The antioxidant of ethanol extract was maximum $(8.25 \mathrm{~m}$ moles TE/g FW) in fruits treated with hot water at $55^{\circ} \mathrm{C}$ while, it was minimum $(3.74 \mathrm{~m}$ moles $\mathrm{TE} / \mathrm{g}$ $\mathrm{FW})$ in fruits treated with hot water at $45^{\circ} \mathrm{C}$ on $21 \mathrm{~d}$ of storage. In methanol extract, the FRAP antioxidant estimated was highest on the 14 day of storage in all treatment thereafter it decreased up to 28 day of storage. It was maximum $(8.0 \mathrm{~m}$ moles TE/g FW) and minimum (4.50 m moles TE/g FW) in hot water treated fruits at $55^{\circ} \mathrm{C}$ on the 14 and 28 day of storage, respectively. The per cent inhibition of antioxidant by DPPH method exhibited highest per cent $(82.49 \%)$ on the day of harvest thereafter it decreased continuously up to 28 day of storage (Fig. 1F.). At the end of the storage period of 28 day the inhibition per cent was maximum $(60.92 \%)$ in hot water treated fruits at $50{ }^{\circ} \mathrm{C}$.

Pomegranates heat-treated at $45{ }^{\circ} \mathrm{C}$ exhibited higher total antioxidant activity than controls. It was correlated to high levels of total phenolics and less to ascorbic acid and anthocyanin contents as reported by (Mirdehghan et al., 2006) ${ }^{[20]}$. Low temperature heat treatments $\left(45^{\circ} \mathrm{C}\right)$ maintained the phenolic compounds and antioxidant capacity of "Red Fiji" apples as noticed by (Li-Li et al., 2013). Hot water at $50^{\circ} \mathrm{C}$ significantly increased the phenolic and antioxidant in Satsuma mandarin (Shen Yu et al., 2013) ${ }^{[27]}$. 


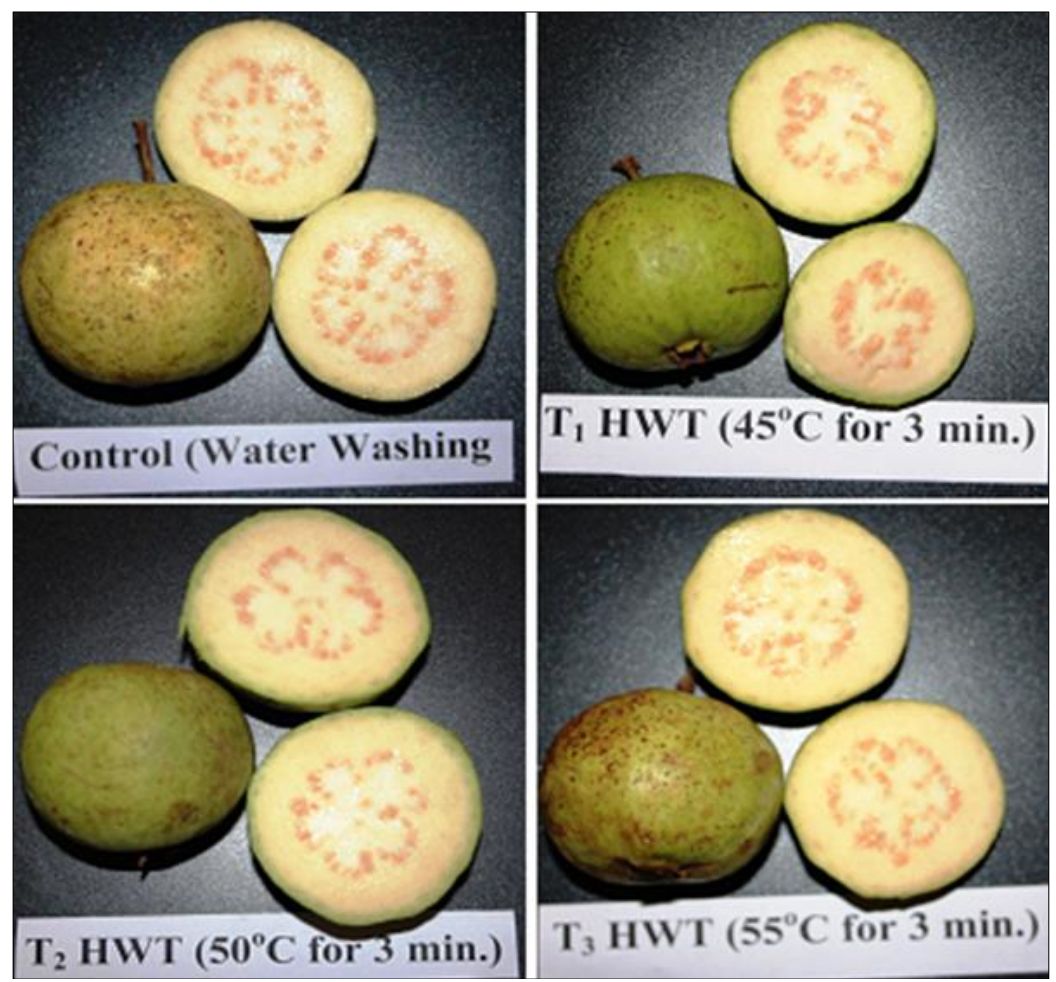

Plate 1: Guava fruits treated with hot water on $28^{\text {th }}$ day of storage at $5 \pm 2^{\circ} \mathrm{C}, 85-90 \%$ R.H
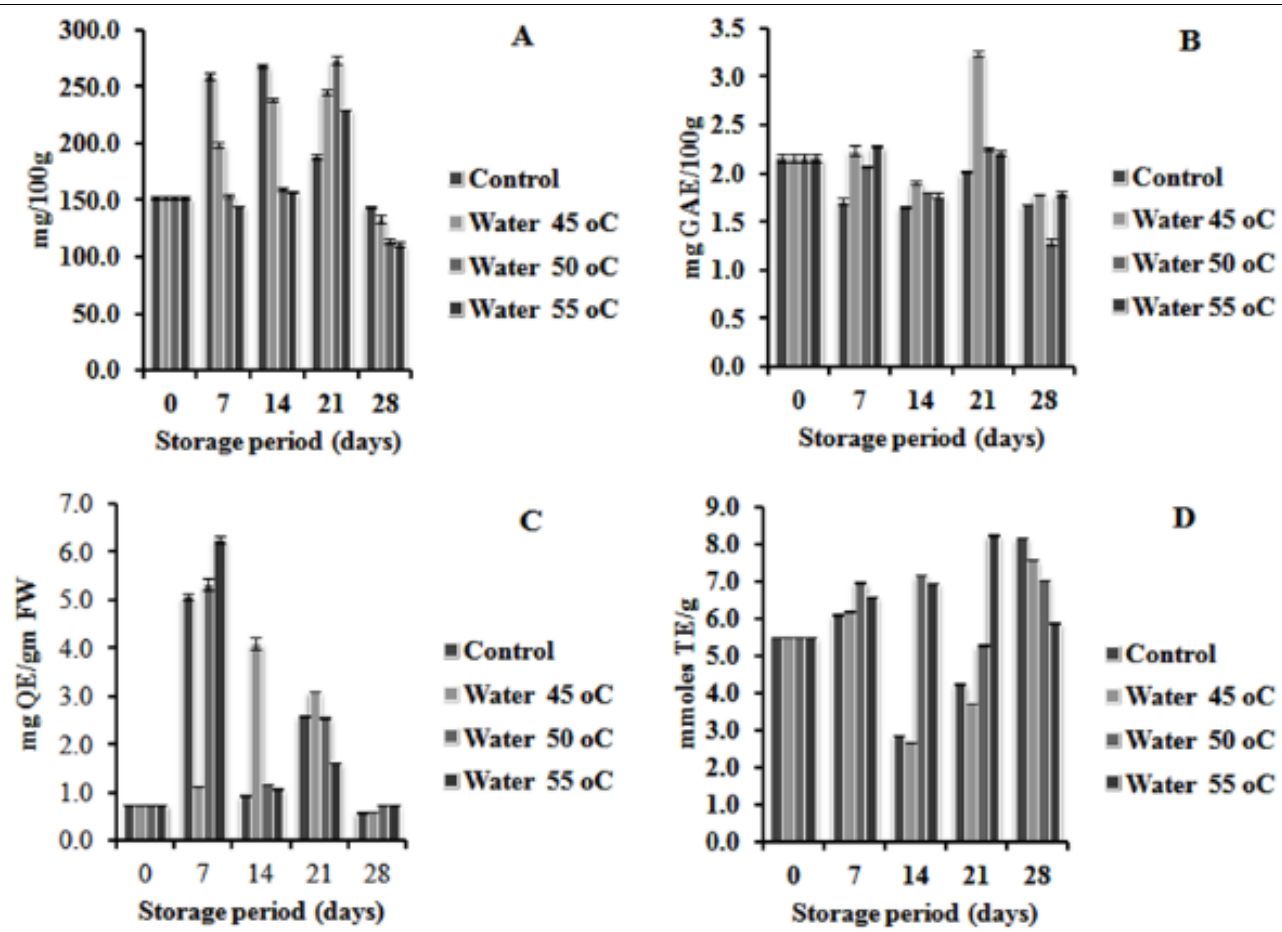

D
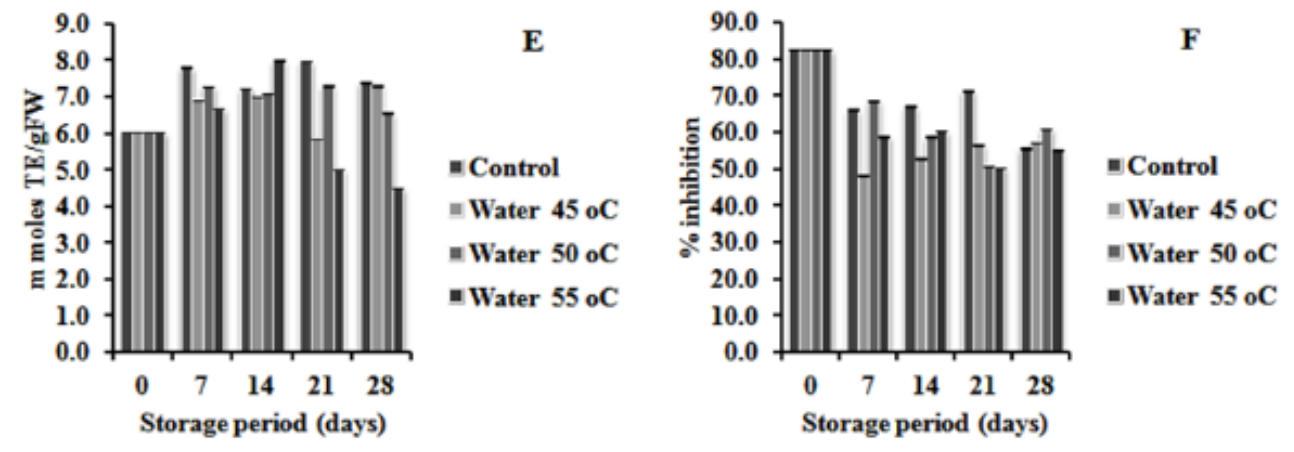

Fig 1: Effect of hot water treatments on (A) ascorbic acid (mg/100g), (B) total polyphenol (mg GAE/100g), (C) total flavonoid (mg QE/gm), (D) antioxidant ethanol extract (m mole TE/g), (E) antioxidant methanol extract (m mole TE/g) and (F) antioxidant DPPH (per cent inhibition) during storage of guava fruits cv. 'Shweta' 
Table 1: Effect of hot water treatment with different temperatures to guava (cv Shweta) on physico-chemical properties of fruits after different period of storage in cold storage condition

\begin{tabular}{|c|c|c|c|c|c|}
\hline & \multicolumn{5}{|c|}{ Storage Period (Days) } \\
\hline & $\mathbf{0}$ & 7 & 14 & 21 & 28 \\
\hline Treatments & \multicolumn{5}{|c|}{ CPLW (\%) } \\
\hline Control & - & $4.28(0.01)$ & $5.84(0.01)$ & $9.44(0.02)$ & $15.60(0.02)$ \\
\hline Hot water $45^{\circ} \mathrm{C}$ & - & $2.75(0.02)$ & $4.01(0.00)$ & $6.15(0.01)$ & $8.66(0.01)$ \\
\hline Hot water $50^{\circ} \mathrm{C}$ & - & $3.96(0.05)$ & $5.75(0.03)$ & $6.75(0.02)$ & $10.15(0.01)$ \\
\hline \multirow[t]{2}{*}{ Hot water $55^{\circ} \mathrm{C}$} & - & $3.85(0.01)$ & $5.03(0.02)$ & $8.86(0.01)$ & $10.37(0.00)$ \\
\hline & \multicolumn{5}{|c|}{ Electrolyte Leakage (\%) } \\
\hline Control & - & $26.00(0.03)$ & $40.37(0.01)$ & $51.46(0.01)$ & $62.94(0.01)$ \\
\hline Hot water $45^{\circ} \mathrm{C}$ & - & $22.65(0.02)$ & $32.45(0.01)$ & $47.18(0.11)$ & $53.85(0.01)$ \\
\hline Hot water $50^{\circ} \mathrm{C}$ & - & $22.93(0.01)$ & $33.35(0.01)$ & $47.45(0.01)$ & $58.54(0.01)$ \\
\hline \multirow[t]{2}{*}{ Hot water $55^{\circ} \mathrm{C}$} & - & $25.65(0.01)$ & $36.23(0.01)$ & $50.71(0.01)$ & $60.00(0.01)$ \\
\hline & \multicolumn{5}{|c|}{ Firmness $\left(\mathrm{kg} / \mathrm{Cm}^{2}\right)$} \\
\hline Control & $12.43(0.07)$ & $10.83(0.09)$ & $9.40(0.10)$ & $8.27(0.07)$ & $5.47(0.07)$ \\
\hline Hot water $45^{\circ} \mathrm{C}$ & $12.43(0.07)$ & $12.27(0.07)$ & $11.80(0.06)$ & $11.07(0.13)$ & $8.33(0.07)$ \\
\hline Hot water $50^{\circ} \mathrm{C}$ & $12.43(0.07)$ & $12.27(0.03)$ & $11.57(0.03)$ & $10.27(0.07)$ & $7.93(0.13)$ \\
\hline \multirow[t]{2}{*}{ Hot water $55^{\circ} \mathrm{C}$} & $12.43(0.07)$ & $12.17(0.03)$ & $11.47(0.07)$ & $10.93(0.13)$ & $8.13(0.07)$ \\
\hline & \multicolumn{5}{|c|}{$\mathbf{T S S}^{\circ} \mathbf{B}$} \\
\hline Control & $9.53(0.03)$ & $10.33(0.07)$ & $12.17(0.03)$ & $10.87(0.07)$ & $11.37(0.03)$ \\
\hline Hot water $45^{\circ} \mathrm{C}$ & $9.53(0.03)$ & $12.23(0.03)$ & $11.47(0.07)$ & $10.20(0.12)$ & $11.77(0.07)$ \\
\hline Hot water $50^{\circ} \mathrm{C}$ & $9.53(0.03)$ & $10.93(0.07)$ & $12.27(0.07)$ & $12.10(0.06)$ & $11.27(0.07)$ \\
\hline \multirow[t]{2}{*}{ Hot water $55^{\circ} \mathrm{C}$} & $9.53(0.03)$ & $11.27(0.03)$ & $11.33(0.07)$ & $11.53(0.07)$ & $11.73(0.07)$ \\
\hline & \multicolumn{5}{|c|}{ Titratable acidity (\%) } \\
\hline Control & $0.23(0.00)$ & $0.31(0.01)$ & $0.38(0.01)$ & $0.36(0.00)$ & $0.31(0.01)$ \\
\hline Hot water $45^{\circ} \mathrm{C}$ & $0.23(0.00)$ & $0.43(0.00)$ & $0.48(0.00)$ & $0.46(0.00)$ & $0.27(0.00)$ \\
\hline Hot water $50^{\circ} \mathrm{C}$ & $0.23(0.00)$ & $0.39(0.00)$ & $0.46(0.00)$ & $0.46(0.00)$ & $0.35(0.00)$ \\
\hline Hot water $55^{\circ} \mathrm{C}$ & $0.23(0.00)$ & $0.36(0.00)$ & $0.47(0.01)$ & $0.42(0.02)$ & $0.36(0.00)$ \\
\hline
\end{tabular}

*Figures in the parenthesis are standard error of mean

\section{Conclusions}

Heat treatments for minimization of post harvest loss is of continues and considerable interest by researchers. The potential of treatment with $45{ }^{\circ} \mathrm{C}$ for $3 \mathrm{~min}$ is effective in extending the shelf life of guava 'Shweta' for 28 days under cold storage $\left(5 \pm 2{ }^{\circ} \mathrm{C}\right.$ and R.H.85-90\%) in addition to 3 days of storage under ambient conditions. It also maintained the nutritional components like vitamin $\mathrm{C}$, total poly phenols, flavonoids and antioxidants of the fruits during the entire period of storage. Hot water treatments were beneficial for shelf life extension and quality maintenance of guava fruits during storage. Knowledge of thermo tolerance in fruits and decay development in prolong storage may allow the development of more commercial feasible treatments in the value chain.

\section{Acknowledgements}

The authors are thankful to ICAR for funding the research projects. The authors are highly obliged to the Director of the institute and colleagues for their assistance in the research for this paper.

\section{References}

1. Armstrong WJ. Development of a hot-water immersion quarantine treatment for Hawaiian grown 'Brazillian' bananas. J Econ. Entomol 1982;75:787-790. DOI: http://dx.doi.org/10.1093/jee/75.5.787

2. Armstrong WJ, Hansen JD, Hu BKS, Brown SA. Hightemperature, forcd air quarantine treatment for papaya infested with Tephritid fruit flies (Diptera: Tephritidiae). J Econ. Entomol 1989;82:1667-1674. DOI: http://dx.doi.org/10.1093/jee/82.6.1667

3. Atta Aly MA. Effects of high temperature on ethylene biosynthesis by tomato fruits. Postharvest. Biol. Technol 1992;2:19-24. doi:10.1016/0925-5214(92)90023-I
4. Barber HN, Sharpe PJH. Genetics and Physiology of sunscald of fruits. Agric. Meterol 1971;8:175-191.

5. Benzie IFF, Strain JJ. The ferric reducing ability of plasma as a measure of antioxidants power the FRAP assay. Anal. Biochem 1996;239:70-76. doi:10.1006/abio.1996.0292

6. Biggs MS, Woodson WR, Handa AK. Biochemical basis of high temperature inhibition of ethylene biosynthesis in ripening tomato fruits. Physiol. Plant 1988;72:572-578. DOI: 10.1111/j.1399-3054.1988.tb09167.x

7. Bratley CO. Loss of ascorbic acid (vitamin C) from tangerines during storage on the market. Proc. Am. Soc. Hortic. Sci 1939;12:12-22.

8. Couey HM. Heat treatment for control of postharvest disease and insects pests of fruit. Hort Science 1989;24:198-202.

9. Forney CF. Hot water dips extend the shelf life of broccoli. Hort Science 1995;30:1054-1057. SB1.H6

10. Gomez-Galindo F, Herppich W, Gekas V, Sjoholm I. Factors affecting quality and post harvest properties of vegetables: Integration of water relations and metabolism. Critical Reviews in Food Science and Nutrition DOI: $10.1080 / 10408690490424649$

11. Gould WP, Sharp JL. Hot water immersion quarantine treatment for guavas infested with Caribbean fruit fly (Diptera teptridiae). J Econ. Entomol 1992;(85):12351239. DOI: http://dx.doi.org/10.1093/jee/85.4.1235

12. Klein JD. Ethylene biosynthesis in heat treated apples: Clijsters H, de Proft M, Marcelle R, Van Ponche M (Eds), Biochemical and Physiological aspects of ethylene production in lower and higher plants. Kluwer, Dordrecht, the Netherlands 1989, 184-190.

13. Klein JD, Lurie S, Ben-Arie R. Quality and cell wall components of Anna and Granny Smith apples treated 
with heat and calcium and ethylene. J Am. Soc. Hort. Sci 1990;115:954-958. 81 SO12

14. Li-Li, Xihong Li, Aili Wang, Yuqian Jiang, Zhaojun Ban. Effect of heat treatment on physiochemical, colour, antioxidant and microstructural characteristics of apples during storage. International Journal of Food Science and Technology 2013;48(4):727-734. DOI: 10.1111/ijfs. 12020

15. Lurie Susan. Postharvest heat treatments. Postharvest Biol. Technol 1998;14:257-269. http://dx.doi.org/10.1016/S0925-5214(98)00045-3

16. Lum MS, Norazira MA. Effects of hot water, submergence time and storage duration on quality of dragon fruit (Hylocereus polyrhizus). Journal of Agricultural Science 2011;3(1):146-152. DOI: http://dx.doi.org/10.5539/jas.v3n1p146

17. Marzon ME, Biasi B, Wang S, Tang J, Haliman GJ, Mitcham EJ. Persiman and guava fruit response to radio frequency heating as an alternative quarantine treatement. Acta Horticulturae 2004;687:349-350. 10.17660/ActaHortic.2005.687.44

18. McCollum TG, McDonald RE. Electrolyte leakage, respiration and ethylene production as indices of chilling injury in grapefruit. Hort Science 1991;26(9):1191-1192. SB1.H6

19. McDonald RE, McCollum TG, Baldwin EA. Temperature of water treatments influence tomato fruit quality following low temperature storage. Postharvest Biol. Technol 1999; 16:147-155. http://dx.doi.org/10.1016/S0925-5214(99)00008-3

20. Mirdehghan SH, Rahemi M, Serrano M, Guillen F, Martinez-Romero D, Valero D. Prestorage heat treatment to maintain nutritive and functional properties during postharvest cold storage of pomegranate. J Agric. Food Chem 2006;54(22):8495-8500. DOI: 10.1021/jf0615146

21. Paull RE. Response of Horticultural commodities to insect disinfestations treatments. Hort Science 1994;29(9):988-996. SB1.H6

22. Paull RE. Effect of temperature and relative humidity on fresh commodity quality. Postharvest Biol. Technol 1999;15:263-277. http://dx.doi.org/10.1016/S09255214(98)00090-8

23. Paull RE, Chen NJ. Heat shock response in field grown ripening papaya fruit J Am. Soc. Hort. Sci 1990;115:623631. $81 \mathrm{SO} 12$

24. Paull RE, McDonald RE. Heat and Cold treatments, In: Paull R.E., Armstrong, J.W. (Eds.), Insect Pests and Fresh Horticultural Products: Treatments and Responses. CAB International, Wallingford, UK 1994, 191-222.

25. Paull RE, Nancy Jung Chen. Heat treatments and fruit ripening. Postharvest Biol. Technol 2000;21:21-27. http://dx.doi.org/10.1016/S0925-5214(00)00162-9

26. Ranganna S. Hand Book of analysis and quality control for fruits and vegetables products. Second ed. Tata Mc. Grate Hill Publication, Co. Ltd., New Delhi 2000.

27. Shen Y, Zhong L, Sun Y, Chen J, Liu D, Ye X. Influence of hot water dip on fruit quality, phenolic compounds and antioxidant capacity of Satsuma mandarin during storage. Food Science Technol. Int 2013;19(6):511-521. doi: 10.1177/1082013212457669.

28. Seymour GB, John P, Thompson AK. Inhibition of degreening in the peel of banana ripened at tropical temperatures II. Role of ethylene, oxygen and carbondioxide. Ann. Appl. Biol 1987;110:153-161. Accession: 001619569
29. Singleton VL, Orthofer R, Lameula-Raventos RM. Analysis of total phenols and other oxidation substrates and antioxidants by means of Folin-Ciacalteu reagent. Methods Enzymol 1999;299:152-178. http://dx.doi.org/10.1016/S0076-6879(99)99017-1

30. Tian MS, Islam T, Stevenson DG, Irving DE. Colour, ethylene production, respiration and compositional changes in broccoli dipped in hot water. J Am. Soc. Hort. Sci 1997;122:112-116. 81 SO12

31. Vazguez Ochoa RI, Colinas Leon MT. Changes in guavas of three maturity stages in response to temperature and relative humidity. Hort Science 1990;25:86-87. SB1.H6

32. Watada AE. Vitamins. In: Weichmann, J. (Ed.), Postharvest Physiology of vegetables. Marcel Dekker, Newyork 1987, 455-468.

33. Woolf Allen B. Reduction of chilling injury in stored Hass Avocado fruit by $38^{\circ} \mathrm{C}$ water treatments. Hort Science 1997;32:1247-1251. SB1.H6

34. Woolf Allan B, Michel Lay-Yee. Pretreatments at $38^{\circ} \mathrm{C}$ of Hass Avocado confer thermo tolerance to $50^{\circ} \mathrm{C}$ hot water treatments. Hort Science 1997;32(4):705-708. SB1.H6

35. Williams MH, Brown MA, Vesk M, Brady C. Effect of postharvest heat treatments on fruit quality, surface structure, and fungal disease of Valencia orange. Aust. J Exp. Agric 1994;346:1183-1190. doi:10.1071/EA9941183

36. Yu YB, Adams DO, Yang SF. Inhibition of ethylene production by 2, 4-dinitrophenol and high temperature. Plant Physiol 1980;66:286-290. 00320889/80/66/0286/05\$00.00/0

37. Yusof S, Hashim H. Hot water dip verses vapaour heat treatment and their effects of guava (Psidium guajava L.) fruits Acta Horticulturae 1992;292:217-221. DOI: 10.17660/ActaHortic. 1992.292.28

38. Zhishen J, Mengcheng T, Jianming W. The determination of flavonoid content in mulberry and their scavenging effects on superoxide radicals. Food Chem 1999;64(4):555-559. http://dx.doi.org/10.1016/S03088146(98)00102-2 